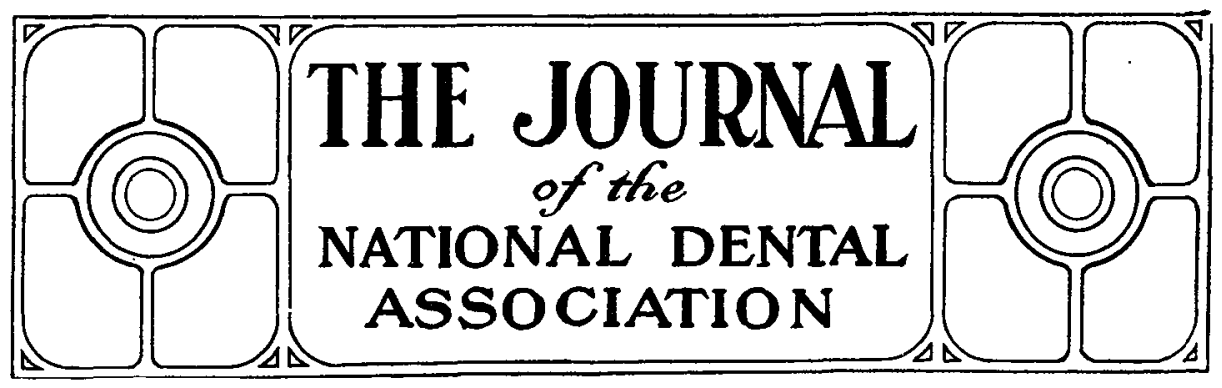

Entered as second-class matter, March 22, 1915, at the Post Office at Huntington, Indiana, under the Act of August 24, 1912. Published Monthly.

Editor and General Manager.

oTTO U. KING. D. D. S., Huntington, Indiana.

Associate Editors,

ThOMAS P. HINMAN, D. D. S., Atlanta, Ga.

HARVEY J. BURKHART, D. D. S., Rochester, N. Y.

THOMAS B. HARTZELA, D. M. D., M. D., Minneapolis, Minn.

office of Publication, Huntington, Indiana.

All expressions of opinion and all statemenis of supposed facts are published on the authority of the writer over whose signature they appear and are not to be regarded as expressing the vlews of the National Dental Association, unless such statements or opinions have been adopted by vote of the Association.

SUBSCRIPTION included in the annual membership dues.

SUBSCRIPTION PRICE, $\$ 2.00$ a year, in advance, to non-members, living in all parts of the United States or its Possessions. Canada, \$2.40. Foreign countries, \$2.75.

ADVERTISEMENTS accepted only from reliable firms. Fraudulent and misleading advertisements barred.

IN CHANGES OF ADDRESS both the old and new address must be given.

RENEWAL BILLS are sent one month in advance. Prompt attention to them prevents discontinuance from the mailing list. Journals are not sent beyond the subscription period.

$\begin{array}{lll}\text { VOL. } 4 & \text { JUNE, } 1917 & \text { No. } 6\end{array}$

\title{
Editorial Department.
}

\section{A MESSAGE TO OUR MEMBERSHIP.}

In this time of war it is necessary for every member of the National Dental Association to do his utmost to help humanity and the United States government. It can be done best by not losing your head, keeping your feet on the ground, and being governed by the rules and regulations given out by the Committee on Dentistry, General Medical Board of the Council of National Defense and the committees of the 
National Dental Association, and nothing else, excepting the United States government. We as an organized body of professional gentlemen, want to furnish the government with the best possible service, and it can be done only thru organization, and that organization working from the center, or head, out-ward and not from the periphery inward. Please bear this in mind, and watch the pages of The Journal of the National Dental Association, and communications from proper committees, and govern yourselves accordingly.

L. L. BARBER, President.

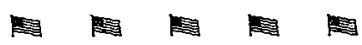

The time has arrived for action. Dentists, especially the younger men, who have been deliberating as to whether or not they should offer their services to the Government should decide now. Not that there is an immediate need for your services, but there is an immediate need that the government should know on whom it can depend so far as its dental officers are concerned.

\section{国 \\ OFFERING YOUR SERVICES.}

We are enclosing in this issue of The Journal of the National Dental Association, an "Application for appointment in the Dental Reserve Corps, U. S. Army." This is the official blank, and gives each dentist the opportunity to act at once.

Those men desiring to join the regular Army Dental Corps, should write to the "Surgeon. General of the Army, Washington, D. C.," for application blanks. An applicant for the regular Dental Corps must be between 21 and 32 years of age, while an applicant for appointment in the Dental Reserve Corps must be between 21 and 55 years of age.

Dentists desiring to enter the Dental Corps of the United States Navy, should write to the "Surgeon General of the Navy, Washington, D. C.," for application blanks for appointment. A candidate for appointment to the Dental Corps of the Navy as dental surgeon must be between 24 and 30 years of age.

The correctness of the statements made in any of the application blanks must be sworn to by the applicant before a notary public or other official authorized by law to administer oaths. It must be accompanied by testimonials based upon personal acquaintance, from at least two reputable persons, as to the applicant's citizenship, character and habits, and by his personal history given in full upon the blank form furnished him for the purpose. 